\title{
A Comparative Study of Government Surveillance of Social Media and Mobile Phone Communications during Iran's Green Movement (2009) and the UK Riots (2011)
}

\author{
Jamileh Kadivar \\ London, UK, Jamileh.Kadivar@Gmail.com
}

\begin{abstract}
In many contexts, social media has been considered as a group of tools that facilitates people's access to freedom and democracy. But this view is challengeable. In this study, two different aspects of social media are examined. The first aspect examines social media's use by protesters in two completely different contexts-Iran and the UK. The second aspect, on the other hand, investigates how the two governments, who have very different approaches to governance, exploited social media in an attempt to control the two protests. The main question addressed in this study is: "What are the differences and similarities between government surveillance of social media and mobile communications during Iran's Green Movement (2009) and the UK riots (2011)?" The findings of this study suggest that social media and mobile phone communications were both important to protesters. Furthermore, this research illustrates that governments monitor the protesters on social and mobile media in different ways, and justify their actions by mainly saying that they do so in order to protect public order and national interests.
\end{abstract}

Keywords: Iran's Green Movement, The UK Riots, Social Movement, Social Media, Mobile phone Communications, Social and Mobile Media, Foucault, Politics, Internet, Technology, Twitter, Surveillance, Panopticon, Big Brother.

\section{Introduction}

In recent years, government surveillance has turned out to be one of the most controversial aspects of people's lives in the convergent media environment. On the one hand, governments note that surveillance is necessary for people's security and public safety and justify it by saying that they are protecting people, and confronting crimes and criminals (Lyon 2001; Fuchs 2012). On the other hand, it seems that the main aim of governments goes beyond keeping citizens secure. In order to retain power, they need to be able to control people, and in order to control people, governments need to collect data on them (Lyon 2001; Lyon 2006; Lyon 2007; Andrejevic 2007). Governments prepare these data from different sources, including the real and virtual world. Social media platforms and mobile phone devices are the main places for collecting information and surveilling users, especially by governments, in the last decade.

Governments and their security services note that they have the right to collect, monitor, read, listen to, and analyse all communications on different social and mobile media platforms and justify their large-scale monitoring of every Facebook, Twitter, YouTube, Google, email, and mobile user activity, and prepare legal justification for their work in these platforms. They feel able to indiscriminately collect and monitor the private or public social media and all web communications.

Information is one of the main sources of power and access to information is crucial to governments, companies, and also to citizens. Therefore, in the struggle between the watchers and those being watched, those who have access to more information are more powerful. In this regard, governments have a unique instrument, using which they can build a monopoly over the virtual and real worlds. Apart from their access to the private information of citizens, they can regulate, make policies, monitor, and limit citizens' access to information. And with all these in mind, it is rather easy to predict the outcome and the winner in this unequal confrontation. 
The reactions of the governments during Iran's Green Movement (2009) and the UK riots (2011) are two major recent examples of government surveillance. Studying Iran and the UK as two countries with completely different ideological, governance, and policy making approaches towards social media, and freedom more generally, can potentially lead to the identification of their similarities and differences towards the two groups of protesters, who had completely different aims, demands and attitudes. Iran's Green movement was a political movement against the fraud in the 2009 presidential election that started in Tehran and expanded to some other major cities, and the primary demand of the people was to count the votes again. The Green Movement was largely a peaceful and non-violent movement. Contrary to the national orientation of Iran's Green Movement, the UK riots were triggered by a local event after the death of Mark Duggan in North London. Objections began peacefully but were then exacerbated by the police attack and caused violent clashes with the police. These protests are considered the worst examples in Iran and the UK's recent history, so governments tried hard to stop them by different means in different ways, especially with the "Iron Fist" in social and mobile media.

This study attempts to provide an investigation into new governments' surveillance methods towards people's protests on social media platforms and mobile phone connections. This study wants to explore the nature of the Iranian and UK governments' policies with respect to people's access to social media and mobile connections during protests, and find out their differences and similarities in this regard.

Many people think governments' surveillance and their restrictions in the real or virtual world are (were) only limited to some totalitarian regimes in developing countries. On the contrary, the reality is completely different. And this is what some politicians, journalists, and experts have not considered during the protests in some developed countries with democratic governance. In essence, this research shows that different governments have the same concerns regarding surveillance on social and mobile media. Therefore, while it is important to study the role of social media amongst protesters, the primary aim of this research is to investigate government surveillance of social media platforms and mobile devices communications in Iran and the UK, because government surveillance on social media platforms is more complicated than other kinds of surveillance.

This study attempts to understand whether these traits extend to the protests in Iran and the UK about government surveillance in 2009 and 2011, and the restrictive measures taken by Iran and the UK governments with regards to stopping the protests, which were partially afforded by some social media platforms and mobile communications. The main focus of this study is: "What are the differences and similarities between government surveillance of social media and mobile communications during Iran's Green Movement (2009) and the UK riots (2011)?" Presenting these two protests in Iran and the UK, and finding why and how the Iranian and UK protesters used social media and mobile phones during their respective protests are the other aims of this research, which define their activities and show later how and why governments surveilled the protesters on social and mobile media.

Following the introduction, the methods of this comparative study are described. Then it tries to point out a more fundamental theoretical framework for the study of social media and politics that is then used later in the paper to interpret the findings. After that, there are indepth reviews of the protests in Iran (2009) and in the UK (2011), and a study of why they used social and mobile media during the protests, how and why the governments tracked the protesters using their activities on social media and mobile communications, and what the governments' policies were regarding social media at that time. Analyses of the similarities and differences between these two protests, also the governments' policies, and attitudes towards social media and mobile phone devices are another parts of this study.

\section{Methods}

This research is a comparative study of two important events in the form of Iran's Green Movement and the UK riots. This study endeavours to obtain an in-depth understanding of the differences and similarities of government surveillance on social and mobile media to- 
wards the Iranian Green movement (2009) and the UK riots (2011), and the role of social media in these two protests. Considering the purposes of this study, the qualitative approach is chosen. Direct observation, interview, and desk research are the main methods for data collecting and analysis. The chain of evidence, based on three kinds of data sources (documents, interviews and direct observations) enables the author to tell the story of cases (and their multiple sub cases) more accurately and comprehensively.

Despite the differences between the aims and nature of protests in Iran (2009) and the UK (2011), and the distinctions between the styles of governance in the two countries, these two cases have been deliberately selected because they provide a better overall picture of similar situations with the same process that have been handled in distinct ways.

This research studies the events during Iran's Green Movement (from 12 June 2009 to 11 February 2010) and the UK riots (from 6 August to 11 August 2011), examines how and why people used social media during these protests, what the governments' surveillance policies were, and how and why they surveilled protestors. I attempted to specify how social media acted for those on both sides of the protests-protesters and governments-and to find the functionalities afforded by social media in Iran and the UK. The gathered information about the two cases helped to explore how governments performed their surveillance activities.

In the initial phase of this study, the aim was to focus on the different evidence relating to Iran's Green Movement and the UK riots, which I gathered by desk research method. The richest source of data was the news, reports provided by the journalists who were present at the scene, interviews or speeches given by the protestors, authorities, government officials, and the police. In the UK there were many published official reports by different governmental and non-governmental organizations. However, in Iran, the number of formal reports that are available for researchers is very limited, although some international organizations such as Amnesty International and Reporter without Borders have published some reports that have been used in this research.

Furthermore, some academic journals, books, videos, and newspaper articles published in The Guardian, The New York Times, the BBC, The Wall Street Journal, Persian news agencies such as ISNA, IRNA, Fars, and websites that belong to main supporters of Green Movements such as Jaras and Kaleme, and various personal weblogs were used. Most of these are readily available through an Internet search. The other sources, especially the books, have been accessed from different libraries.

Conducting interviews with 4 people ( 2 individuals from Iran, and 2 from the UK) who had observed and were familiar with the events was another part of the chain of evidence. The information collected from the interviewees was used in conjunction with other sources, which were explained above. The purpose of the interviews was predominantly to find first hand information from the participants or experts in these two events and fill the gaps that I thought were crucial to bridge. These interviews provided fruitful information and were used as an important part of the information collection sources in my study.

The first interviewee was a 26-year-old male journalist inside Iran (referred to as interview partner 1), who had participated in some demonstrations in Tehran. The second interviewee was a 40-year-old male, an IT engineer, who had participated in all of the demonstrations in Tehran, and around 3 years ago, he had to leave the country (referred to as interview partner 2). The UK interviewees included one journalist and one rioter. The first interviewee (referred to as interview partner 3 ) was with an experienced broadcast journalist and filmmaker, who has made programs for the Guardian, the BBC, Channel 4 and Al Jazeera English. The second interviewee (referred to as interview partner 4) was a 17-year-old black student based in London.

Another considerable source of evidence comes from my direct observation in Tehran (from 13 June to 8 July 2009) and London (8th August 2011 as a bystander in Oxford Circus, and Harrow). Direct observation is of crucial importance because people behave as they normally do without being disturbed by observers.

The analysis of data firstly involved providing a description of each case (Iran's Green movement and the UK riots). The next stage was to study the real-world context in which social media were used in both countries during the protests. The different functionalities 
afforded by social media and mobile phones were then studied. Finally, the governments' surveillance activities towards the protesters, and the reasons behind their reactions were analysed.

\section{Theoretical Framework}

This chapter is organized to describe the theoretical framework to realize government surveillance on social media and mobile communications in two cases, and structured as follows: first, an examination of the literature on government surveillance as a theoretical framework is provided. Secondly, two different approaches concerning the role of new technologies in the protests are investigated.

\subsection{Government Surveillance}

In order to understand government surveillance, this study looks at the Panoptic and the Orwellian models, which form the foundations of this study.

\subsubsection{Panopticon}

"Panopticon" has been one of the most influential concepts in surveillance studies. "Panopticion", meaning "all-seeing place", stems from Bentham's architectural design for a highly efficient prison (Chadwick 2006, 261). It is through the Panopticon, that Bentham has made his impact on contemporary theoretical debates. He described Panopticon as a building designed for surveillance in the $18^{\text {th }}$ century. According to Bentham (45) In panopticon prison "the apparent omnipresence of the inspector' is combined with the extreme facility of his real presence". However, all of the inspector's power over the prisoners derives from his invisibility, or more precisely, his "invisible omnipresence" (Bozovic 1995, 9).

What is important in the panopticon is the illusion of constant surveillance. As Bozovic notes "the prisoners are not really always under surveillance, they just think or imagine that they are" $(1995,15-16)$. Therefore, the possibility of being observed at any time leads the observed person to "internalise" the work of surveillance. So, it is not necessary to inspect them at all times. People modify and adjust their behaviour in the panopticon system. Because "every prisoner will think that he himself is constantly under the gaze of the inspector, and that none of his movements can escape the ever wakeful, watchful eye of the inspector" (Bozovic 1995, 16). As a result, discipline is internalized in the prisoners' minds and gradually metamorphoses and transshapes them. Gill $(2003,135)$ notes, "we can define panopticon as 'a dystopia latent in modernity: the possibility of developing a system of control, which reduces the individual to a manipulable and relatively inert commodity".

Although Bentham's proposal was never put into practice in its entirety, its principles have informed many kinds of surveillance technologies and processes, from closed circuit Television (CCTV) to supermarket loyalty cards through to company managers' enthusiasm for instant messaging technologies (Chadwick 2006, 261).

\subsubsection{Big Brother}

Another key term in different contexts is "Big Brother" (Orwell 1949), especially in government surveillance where it is cited in many academic books and articles (Foucault 1977; Morozov 2011; Fuchs 2012; Lyon 2012; Meikle and Young 2012). Orwell focused his attention exclusively on the nation-state acting in a simple top-down fashion (Chadwick 2006, 260). In the society that Orwell describes, everyone is under complete surveillance and control by the authorities and people know Big Brother is watching them anytime and everywhere, so that they may be watched or listened to at any time.

\subsubsection{Disciplinary Power and Panopticon}

Government surveillance in social media is indebted to Foucault's writing. Panopticon, visibility, power and control are also important terms in Foucault's writing. Foucault (1977) emphasizes the administrative and legal hierarchies for social control and the growth of disciplinary 
society as a whole. He also mentions different places in which it is possible to control the use of an individual's time and space hour by hour. He writes "inspection functions ceaselessly. The gaze is alert everywhere [...]" (Foucault 1977,195). In his view, power and knowledge come from observing others. The more one observes, the more powerful one becomes (Foucault 1977). For Foucault, surveillance is a form of disciplinary power and disciplines are "general formulas of domination" (Foucault 1977, 137). A person that is under surveillance "is seen, but he does not see; he is the object of information, never a subject in communication" (Foucault 1977, 200). For him, surveillance is a "system of permanent registration [...] in which all events are recorded" $(1977,196-197)$.

\subsection{Internet Surveillance and Politics}

Nowadays, Internet surveillance has important implications in politics to control, protect, and influence (Castells 2001; Fuchs et al. 2012). While governments worry about the capacity of social media and communications instruments, they have the ability to control the Internet, restrict it, or shut it down. As Meikle and Young have argued, "even in the convergent media world, government policy does matter" $(2012,172)$. Furthermore, Resnick notes that three relevant politics should be taken into account: "Politics within the Net, politics which impacts the Net, and political uses of the Net" $(1998,55)$. All these three aspects are important in this study.

Moreover, Lyon explains that "surveillance is any collection and processing of personal data, whether identifiable or not, for the purpose of influencing or managing those whose data have been granted [...]" and adds "Today, the most important means of surveillance reside in computer power [...]" (Lyon 2001, 2). He has noted how government's surveillance works through the Internet and shows relations between technology and society in surveillance society and argues that to understand what is happening we have to go beyond Orwellian alarms. According to Lyon, surveillance is an ordinary part of everyday life $(2013,9)$.

Furthermore, Marx mentions that, "computerized surveillance is an important form of new surveillance which changes the nature of surveillance over time and across space" (2002, 208). In a similar way, Andrejevic (2007) writes how new technologies are increasingly employed as modes of surveillance and control and argues that all our data is being collected in different places and during different activities. He claims that the benefits of new media are accompanied by hidden risks and potential threats and notes that governments track hidden information during the protests and they can follow the protesters by surveillance (Andrejevic 2007). Moreover, Fuchs argues that surveillance is a concept that is inherently linked to information gathering for the purpose of domination, violence, and coercion $(2014,213)$. He (2014) points out that technologies of freedom have the capacity to be technologies of control, and that communication and surveillance have always gone hand in hand.

While Petersen (2013) discusses surveillance as a phenomenon and writes that surveillance is a divisive issue which is a more important point during the protests, Boghosian (2013) argues that personal information in our emails, phone calls, GPS movements and different social media platforms is a commodity and points out that corporations are cashing in by selling the data they collect about our private lives and discusses how the government uses such information. Similarly, Trottier (2011) emphasizes that "Police can obtain information on social media through conventional and unconventional means. Social media services have opened up official channels for the police to obtain private information from their servers".

\subsection{The Role of New Technologies in the Protests}

There are two completely different views about the role of new technologies and social media in social movements and protests: techno-optimists and techno-pessimists. 


\subsubsection{Techno-Optimism}

Some techno-optimists such as Castells and Shirky, who stress the role of social media in social movements and believe in new media, played a key role in the changes during the last years. They are optimistic about the effects of social media on politics. Castells points out that Internet and social media communication generates movements in the streets, and argues that "the digital social networks based on the Internet and wireless platforms are decisive tools for mobilizing, organizing, deliberating, coordinating and for deciding" $(2012,229)$.

Furthermore, Shirky argues that social media would be a "coordinating tool for nearly all of the world's political movements, just as most of the world's authoritarian governments (and, alarmingly, an increasing number of democratic ones) are trying to limit access to it" (Shirky $2011,30)$. While Shirky accepts that governments try to control, censor and monitor social media, he points out that social media applications are tools that can strengthen civil society and the public sphere (Shirky 2011, 32) and encourage revolution.

\subsubsection{Techno-Pessimism}

On the other hand, there are some techno-pessimists, such as Gladwell and Morozov, who underestimate the role of social media in the movements. Gladwell argues that the revolutions will not be tweeted (Alexander and Hanson 2013) and points out that social media would make it easier for activists to express themselves, and harder for that expression to have any impact $(2010,49)$. Furthermore, he believes that social media is not a natural enemy of the status quo social media applications are actually well suited to making the existing social order more efficient $(2010,49)$.

Morozov (2014), like Gladwell, is sceptical of the role of social media in social movements, and says, "When the Internet is everywhere, politics is nowhere". He (2009a) denies the view that the Internet acts as a revolutionary force that empowers people and explains that the Web is as likely to distract as to empower, and that both dictators and dissidents can exploit it. The theoretical framework helps to explain more accurately how activists, rioters and governments have used social media in Iran (2009) and the UK (2011).

\section{Findings}

In this section firstly the role of social and mobile media in Iran's Green Movement (2009) and the UK riots (2011) is defined, and then government surveillance in the two countries is explained.

\subsection{Iran's Green Movement}

On 13 June 2009, Iran's Interior Minister Sadeq Mahsouli announced that Ahmadinejad won with $62.63 \%$ of the total votes in the presidential election, while Mousavi had $33.75 \%$ of the votes (Fars 2009). When the results were announced, people realised that their votes were missing. This was the main impetus of the Green Movement (Dabashi 2010). So, the protests were not about religious reform, nor were they about regime change, instead, they were sparked by "a passion for maths" (Cross 2010,169).

Claims of vote fraud triggered massive street protests. At first, protesters only demanded a vote recount, but after a violent reaction from the police, their demands became more radical. Iran was facing its most serious political crisis since the 1979 revolution. Many took to the streets with "Green" signs, chanting slogans such as "the government lied", "where is my vote?", and later "death to the dictator" (Jaras 2009).

Demonstrations took place steadily throughout June until mid-July 2009, and continued occasionally on days of national significance, whenever public demonstrations were allowed. "The demonstrations that took place during Ashoura (December 27, 2009) were the last mass demonstrations to occur since the election [...] Attempts to hold further demonstrations were prevented by the heavy presence of security forces" (Amnesty International 2010b) and this trend continued after that until the house arrest of Mousavi and Karroubi in 2011. 


\subsubsection{The Role of Social and Mobile Media}

There is no doubt that social media has played a role in Iran's contemporary politics. So, in this research the use of social media is not debated, but the extent of this use is.

According to Internet World Stats (IWS) Internet users in 2009 account for approximately $48.5 \%$ of the population of Iran. In 2009 , Iran had 30.2 million mobile phone users (Freedom House 2009; 2011), and 72 cellular subscriptions for every 100 people (World Bank, no date). Today, while Iran has the $19^{\text {th }}$ largest population in the world, its blogosphere holds the third spot in terms of number of users, just behind the United States and China (Beth Elson et al. 2012).

There have been numerous debates about social media's role in Iran during the Green Movement. This subject has received interest from different corners of the world, including Western countries, Iranian authorities, opposition groups, and also some NGOs. Some believe social media is the main cause of the protests, some think its role was limited to organizing the protests and mobilizing the protesters, and others point to its role in the publicizing of the events. Perhaps it is because of these views about the importance of social media during the demonstrations that the government increased its efforts to restrict social media.

Reporters Without Borders (2010) issued a statement, saying that, "the new media, and particularly social networks, have given populations collaborative tools with which they can change the social order". According to Beth Elson et al. $(2012,8)$ "The Green Movement relied heavily on Twitter, Facebook, text messaging, and the thousands of blogs created by ordinary Iranians to quickly organize and coordinate opposition efforts and public demonstrations, as well as to disseminate doctrine and political manifestos".

It has also been mentioned that despite efforts by the Iranian government to prevent any reporting of the protests and due to considerable pressure placed on foreign journalists inside Iran, social media played a significant role in sending the messages and images of the movement to the outside world (Alizadeh 2010; Axworthy 2014). However, at that moment, many thought that Twitter performed a liberating role for Iranian dissenters. For example, Western media heralded the Green Movement in Iran as a "Twitter revolution" fuelled by information and communication technologies (ICTs) and social media tools (Carrieri et al. 2013 , 4). "The Revolution Will Be Twittered" was the first in a series of blog posts published by Andrew Sullivan (2009) a few hours after the news of the protests was released.

While many noted that "it is impossible to determine how many Iranians use Twitter" (Beth Elson et al. 2012, 12), Evans (2009) revealed that "there are now 19,235 Twitter users in Iran, compared with 8,654 in mid-May". He explained that "on June 19, 40.3\% Tweets about the election came from outside Iran as the media and blog coverage about the protests in Tehran attracted global attention". Similarly, El-Nawawy (2012) noted "They called it the "Twitter Uprising" without considering how many twitter users actually come from inside Iran". Furthermore, The Web Ecology Project (WEP 2009) confirmed that most of the tweets about the election came from outside Iran. Due to a small percentage of tweets, which originated in Iran, it seems Twitter has been used as a system for publicizing events in Iran to the rest of the world instead of as an organizing tool for Iranians during protests (Ems 2014).

The most frequently circulated story from the Iranian protests was a video of Neda AghaSoltan. Her final moments were captured by some bystanders with mobile phone cameras and rapidly spread across the global media and the Internet. It showed that the cameraphone had provided citizens with a powerful means, allowing for the creation and instant sharing of persuasive personalized eyewitness records with mobile and globalized target populations (Anden-Papadopoulos 2014). This video was distributed many times through Twitter, Facebook, and YouTube.

Interview partner 2 noted that, "mobile phone and social media have played an important role in the protests. Firstly, they helped to exchange information and hold discussions between protesters, and sometimes they were used for organizing and mobilising the protests. Secondly to inform the world about what was happening in Iran". The interview partner mentioned that, "mobile played a more significant role than other tools". Interview partner 2 also argued that Twitter and Facebook were not as important as text messaging. Moreover, the 
interviewee mentioned that, "Western media has exaggerated the role of Twitter and Facebook in the Green Movement". On the other hand, interview partner 1 believed that social media had not penetrated much among ordinary people at the time, and that they were mostly under the influence of Iran's state-owned TV and Radio. Furthermore, the interviewee noted that, "satellite channels were more influential tools than Facebook and Twitter for protesters". Both interview partners 1 and 2 rejected the "twitter revolution" or "social media revolution" claims.

According to the author's observation social media was most useful in the dissemination of information, especially from those inside Iran to outsiders. On the other hand, based on the personal observations of the author, mobile phones were mostly influential as an instrument firstly used for producing contents (images and videos) and secondly for the organisation of protests. I also found that the traditional word-of-mouth communication played a key role in the organizing and mobilizing of protests.

\subsubsection{Government Surveillance of Social Media and Mobile Phone Communications}

While the protesters used social media during the movement, the Iranian authorities used it against the protesters too.

The Iranian government had improved its technical capabilities to monitor people's behaviour on the Internet long before the 2009 election. The election led to an increase in online surveillance. Through using social media, the Iranian government became even more powerful than it was before the election. The intensified filtering of the Internet and implementation of more advanced surveillance systems strengthened the government's position after the election. The Open Net Initiative (2009) revealed that the Internet censorship system in Iran is one of the most comprehensive and sophisticated censorship systems in the world. It emphasized that, "advances in domestic technical capacity have contributed to the implementation of a centralized filtering strategy and a reduced reliance on Western technologies".

Iranian authorities (IRNA 2009; ISNA 2009) believed that the position of Western countries and their media during the protests was a clear sign confirming Iran's suspicions that Western governments had been behind the protest. In this regard, Morozov (2010) argues that the Iranian government believed the Western policymakers' bluff and took aggressive countermeasures, making the job of using the Web to foster social and political change in Iran harder. So, a number of protesters who were put on trial after the election were accused of their online activities on Facebook and other websites.

Interview partner 1 mentioned that the interrogator had confronted him with copies of his emails and had questioned him about his online activities on Facebook. Interview partners 1 and 2 both argued that the main policies of government after the election were increasing the filtering, blocking, satellite jamming, and censorship. Interview partner 1 also said that he found his electronic communications were being monitored.

On the other hand, the authorities attempted to block all access to political blogs (Jaras 2009), either through cyber-security methods or through threats (Tusa 2013). The Iran Revolutionary Guard Corps (IRGC), along with the intelligence ministry each have their own, separate Internet-monitoring units that tracked prominent political figures and activists (Fassihi 2009). The Centre for Investigating Organized Cyber Crimes, founded in 2007 partly "to investigate and confront social and economic offenses on the Internet" (Cyber Police 2009; ISNA 2009), became increasingly important over the course of 2009 as the regime combated the opposition's online activities (Beth Elson et al. 2012,16). Training of "senior Internet lieutenants" to confront Iran's "virtual enemies online" was another attempt that the Intelligence minister announced following the protests (Iran Media Program 2013).

In 2009, the government enacted the Computer Crime Law (Jaras 2009; IRNA 2009). In the late fall of 2009, the government started sending threatening and warning text messages to protesters about their presence in the protests (BBC 2009). Attacking, blocking, hacking, and hijacking of the domain names of some opposition websites such as Jaras and Kaleme, besides a number of non-Iranian sites such as Twitter, were among the other attempts of the Iranian Cyber Army (Jaras 2009). Moreover, the Revolutionary Guard demanded that Iranian 
websites remove any material that "create[d] tension" or the sites would face legal action (BBC 2009; Holmwood and Kamali Dehgan 2009; Jaras 2009). Furthermore, some websites that were inciting violence or encouraging people to protest were threatened with legal action. It is also said that the police and security forces arrested dissidents identified through photos and videos posted on the social media that many imagined had empowered them. Furthermore, the online photos of the active protesters were posted on different websites, asking people to identify them (Valizadeh 2011).

In late June 2009 the Iranian government was intentionally permitting Internet traffic to and from social networking sites such as Facebook and Twitter so that it could use a sophisticated practice called Deep Packet Inspection (DPI) to collect information about users. It was reportedly also applying the same technology to monitor mobile phone communications (Beth Elson et al. 2012,15). DPI is a surveillance technology that makes it possible to monitor not only the meta-data of Internet communication (sender, recipient, type of data, etc.), but also the sent content (Fuchs 2013). Fuchs (2013) emphasises the political-economic aspects of selling DPI and believes those deals were profitable for homeland governments and Western companies.

On the other hand, to cut communication between Iranians inside and outside the country, Iran slowed down the Internet dramatically (Jaras 2009). Iran also blocked access to Facebook, YouTube, Wikipedia, and Twitter and many blogs before, during or after the protests. My weblog was among many other blogs that were blocked in 2009. I also, like many other people, had lots of problems contacting my family and friends both inside and outside Iran after June 2009 due to communication problems. Furthermore, in 2009, text message services were shut down for over 40 days, and mobile phone subscribers could not send or receive text messages regardless of their mobile carriers. Subsequently it was disrupted on a temporary basis immediately before and during key protests days.

Amnesty International (2010a) reported: "the authorities suppressed freedom of expression to an unprecedented level, blocking mobile and terrestrial phone networks and Internet communications. In April, they warned SMS users that messages were 'controlled' by a new 'internet crimes' law introduced in January". It was later discovered that the Nokia Siemens Network provided the government with surveillance technologies (Wagner 2012; Iran Media Program 2013). The Iranian government built a complicated system that enabled it to monitor, track and intercept what was said on mobile phones. Nokia Siemens Network confirmed it supplied Iran with the technology needed to monitor, control, and read local telephone calls... The product allowed authorities to monitor any communications across a network, including voice calls, text messaging, instant messages, and web traffic (Jones 2009). A journalist, jailed following information collected by this "communication monitoring service", said, "the most unbelievable thing for me is that Nokia sold this system to our government" (Bakhtavar 2009, 202-203).

Media sources also reported that two Chinese companies, Huawei and ZTE, provided surveillance technologies to the government. The Nic Payamak and Saman Payamak websites, that provide mass text messaging services, also reported that operator Hamrah Aval commonly blocked texts with words such as meeting, location, rally, gathering, election and parliament (Iran Media Program 2013).

Another problem after the 2009 protests was the sense of vulnerability among Iranians abroad who found themselves vulnerable to "social media" harassment by the Iranian police and security forces (Tribunal decisions no date).

After the protests, the Internet-monitoring units expanded their responsibilities and began monitoring the online activity of Iranians abroad as well. Receiving a threatening email because of their online or offline activities was one of their problems. Fassihi (2009) noted that some people, who had travelled to Iran after June 2009, were arrested and questioned about their Facebook accounts or posts online.

The personal observation of the author confirms that some friends were questioned about their online activities, and asked to answer the questions about themselves and others, when they went to the airport. My experience also indicates that my activities on social and mobile media were surveilled inside and outside Iran. 


\subsection{The UK Riots}

The UK riots began as a small-scale and peaceful protest in Tottenham, on 6 August against the police shooting of a local black man (Lewis et al. 2011, 15). While Milburn $(2012,402)$ claims that the 2011 disturbances emerged from a 'context of crisis and austerity', PlattsFowler $(2013,28)$ argues that perhaps the rioters' actions are 'political' if they are rioting because something is definitely not right. On the other hand, Tottenham's MP, David Lammy notes that many of the protesters were not from Tottenham. Lammy mentioned 'a peaceful demonstration was hijacked by a "small number of criminal elements"' (Gabbatt and Quinn 2011).

The riots occurred in sixty-six locations, involving an estimated 15,000 people. The consequent financial loss across the country was approximately half a billion pounds (Bridges $2012,1)$. It is estimated that about 2,500 shops and businesses were looted across England (Lewis et al. 2011, 27). The cost in insurance claims to the London economy alone was estimated to be up to $£ 300 \mathrm{~m}$ (Rogers 2011).

So, as a bystander to the riots in London (on 8 August 2011), who witnessed the disorder and looting, it is important to know why the UK riots happened, why a peaceful protest in Tottenham turned into violent riots, how the rioters benefited from social media and BlackBerry Messenger (BBM) service, and how the government managed the crisis through using the same tools.

\subsubsection{The Role of Social and Mobile Media}

The idea that social media and mobile phones caused the UK riots has been mentioned many times by the Prime Minister (2011a; 2011b), the Metropolitan Police, MPs, and various newspapers. These voices "pointed the finger at social media use as playing a major role in the riots" (Casilli and Tubaro 2012, 6). They reflected social media determinism that overrates the positive or negative roles of technology in society and ignored other important factors.

Economists (August 13, 2011) wrote "AS BRITONS ask themselves what has changed in their country that might have caused these riots, one obvious answer stands out: technology. The digital revolution allows people to organise themselves against the authorities-not just in the Middle East, but also in Britain".

Despite the attention paid to social media by the government and the press, some suggested that the traditional media, particularly television, played an important part and argued that the blanket media coverage by broadcast media and social media both had an imperative role in the spreading of the riots (Lewis et al. 2011, 33). Furthermore, Morrell et al. (2012, 36) noted "Television news was clearly important, with young people also receiving more information about local events via social media (Facebook and BBM) and text messaging. Whilst social media did not necessarily trigger involvement, it undoubtedly speeded up the exchange of information and increased the number of young people aware of the events as they were happening".

According to The Home Affairs Select Committee (2011), "the single most important reason why the disorder spread was the perception, relayed by television as well as social media, that in some areas the police had lost control of the streets". It emphasised that some of those who took part in the disturbances did use social media to communicate with each other, but television also played a part in spreading the disorder.

On the other hand, using BlackBerry handsets-the smartphone of choice for $37 \%$ of British teens, according on Ofcom study (2011) -BBM allows users to send one-to-many messages to their network of contacts that are connected by "BBM PINs". And unlike Twitter or Facebook, many BBM messages are untraceable by the authorities (Dzaieza 2011; Wells and Jones 2012).

Akwue, who noted the role of Blackberry for the first time in the UK riots (2011a), in another article wrote BlackBerry did not cause the riots and is not responsible for them. BBM is simply the preferred communications network for large numbers of young people, and when they are angry and sufficiently organised - the results can be explosive (2011b). 
While interview partner 4 said "he was not on Facebook or Twitter, and that the protesters would connect with each other using BBM mostly, because it was cheap, safe and easy", interview partner 3 explained that "BBM appeared to play quite a significant role in the riots, in the sense that it allowed people to be alerted as to where rioting was taking place (or sometimes where it was about to take place) [...] They all used BBM to communicate with each other".

An examination of the reactions of the politicians and the police revealed that social media played two contradictory roles in the UK riots. The first role is a rather negative one, which is when social media was used as a mobilizer and organizer tool for rioters. For example, Cameron said, "everyone watching these horrific actions will be struck by how they were organised via social media" (Halliday 2011c). Similarly, Theresa May, the Home Secretary (2011a) emphasised that social media 'have been used to co-ordinating criminality and staying one step ahead of the police'. In an interview with the BBC (2011), a senior police officer noted that online tools were responsible for the violent riots. Also, the Conservative MP for Enfield North argued that the disorder in Enfield was encouraged via social media websites (Globalpost 2011). Additionally, some researchers believe that social media played a key role in transmitting information during the disturbances seen in English cities. Some messages posted on sites such as Facebook and Blackberry Messenger helped mobilise many of the rioters by creating an impression that the police had lost control of these cities (Morrell et al. 2012).

In contrast to the above-mentioned negative aspects of social media in the case of the UK riots, some concentrated on the positive results stemming from social media in the UK riots and its role in recovery efforts. A spontaneous volunteer clean-up effort of the city was being organized on Twitter under the hashtag \#riotcleanup, which was trending in London. At the centre of the effort was the Twitter account @riotcleanup, which had attracted almost 70,000 followers in less than a day. There was also a Facebook page for sharing news and information (Brito 2011). A Facebook group had been set up to encourage Londoners to rally round and help with the post-riot clean up (Gabbatt and Adams 2011). Also, eyewitnesses and law enforcement agencies used Twitter to refute a number of unsubstantiated claims in relation to the scale of the disorder that had circulated on the micro blogging site (Procter et al. 2011).

\subsubsection{Government Surveillance of Social Media and Mobile Phone Communications}

While the rioters used social media during the riots, the police used it against the rioters. Subsequent discussion on whether or not social media was "responsible" for the riots and looting in the United Kingdom, the British Government was looking at ways to reduce the likelihood of social media being used to organize riots or violent protest again (McMillan 2011). Officials were considering both banning specific users (Halliday 2011c) from sites like Twitter or Facebook if they were believed to be plotting criminal activity or, much more extremely, empowering the police to essentially close social media access in the U.K. during times of emergency (McMillan 2011). It seems that the British Prime Minister (2011b) was serious about the first option:

[...] When people are using social media for violence we need to stop them. So we are working with the police, the intelligence services and industry to look at whether it would be right to stop people communicating via these websites and services when we know they are plotting violence, disorder and criminality.

Following David Cameron's speech, the British Home Secretary convened a meeting with ACPO, the police, and representatives from the social media industries to work out how they can improve the technological and related legal capability of the police. Among the issues they discussed was whether and how they should be able to stop people communicating via these websites and services when they know they are plotting violence, disorder and criminality, ways of curtailing, or even shutting off, their social-networking functions in an emergency (May 2011b). 
According to the Home Office statement social networking was not a cause of the recent disturbances, but a means of enabling criminals to communicate. So they were working with the police to see what action can be taken to prevent access to those services by customers identified as perpetrators of disorder or other criminal action (IFSEC Global 2011). The Home Affairs Select Committee's conclusion concurred with the final report of the Riots Communities and Victims Panel's view that it may be unhelpful to switch off social media during times of serious disorder. The Home Office in its response to the Committee's report also shared this view. HMIC found that while the police attempted to monitor discussions about rioting on social media to better target response efforts, this fell short of what is possible using modern technology (Singh et al. 2012, 22).

On the other hand, many, including the police $(2011 ; 2012)$, looked initially to Twitter and Facebook to find participants and organizers of the violence (Goodman 2011). The growing presence of the Metropolitan Police and law enforcement initiatives on Facebook, Flickr or Google Groups - not for repressive but for intelligence- gathering purposes -was really helpful (Casilli and Tubaro 2012,17). Also, The Greater Manchester Police (2011) tweeted: "If you have been using social networking sites to incite disorder, expect us to come knocking on your door very soon." The police published pictures of rioters recorded by CCTV and asked the public to identify the people (Fuchs 2011). The police were calling for pictures and information on Twitter at \#tweetalooter and a Facebook page set up to help organise a cleanup of affected areas. The Metropolitan police (2011) had put up a "most wanted rioters" website (Jones et al., 2011a). Along with photos of the clean-up, the web was awash with photos of the rioting and looting. In addition to the official efforts, two independent "name-and-shame" sites also started up. One of them was a Tumbler site called "CATCH A LOOTER", which had been set up in an attempt to identify looters, and the other one was an interactive gallery that let users view one photo at a time and identify persons they recognized, as well as upload their own photos (Brito 2011).

Scotland Yard arrested people suspected of inciting violence across England by using social media. Furthermore, Cameron urged Twitter and Facebook to remove messages, images and videos that could incite more unrest across the country (Halliday 2011c) and Facebook said it had already removed "credible threats of violence" from the site, as well as accounts that were registered under fake names (Pfanner 2011).

Moreover, after announcing that BlackBerry Messenger and Twitter had served as primary communication channels for the rioters, BlackBerry manufacturer Research In Motion (RIM) announced that they'd agreed to cooperate with law enforcement authorities in order to help catch some of the perpetrators. RIM said that it had offered to assist investigators (Schwartz 2011). BlackBerry apologised and said in a statement via Twitter:

[...] We have engaged with the authorities to assist in any way we can. As in all markets around the world where BlackBerry is available, we cooperate with local telecommunications operators, law enforcement and regulatory officials. Similar to other technology providers in the UK we comply with The Regulation of Investigatory Powers Act and cooperate fully with the Home Office and UK police forces.

However, neither the government nor RIM has provided details about this cooperation, or about what, if any, information might have been turned over to the police (Pfanner 2011). In the meantime, it was reported that MI5 and the electronics interception agency GCHQ have been brought in by the Government in an attempt to "crack" the BlackBerry encryption so as to help prevent further disorder (IFSEC Global 2011).

Furthermore, police investigating those responsible for the London riots enabled them to track down and arrest other rioters based on their Blackberry Messenger communications among those who took part (Halliday 2011b). Several arrests indicate that police got their RIM data but mostly they have not said how they got the messages (Wells and Jones 2012). Security experts say it is obvious that the law enables police to request that phone companies hand over traffic information. The Data Protection Act, which normally prevents companies from sharing such information, has a get-out clause for cases where it is clear that a 
crime has been committed (The Economist 2011). According to Reilly (2013) many of these messages would later be used as evidence to prosecute those who participated in the disturbances or incited others to do so.

On the other hand, interview partner 3 explained to the author that "on the nights of the riots the government did not restrict or ban the use of Blackberry or Twitter (and other social media outlets [...] There were a number of rumours floating round after the riots, amongst rioters, that the government had shut down parts of BBM on the night-and that they were surveilling (secretly) people's mobile phone data. But I never found any evidence of this. And I never found anyone who had been arrested, or cautioned, as a result of material sourced secretly on BBM". Interview partner 4 had a different view and argued that some protestors were arrested due to the messages they had sent using their Blackberries.

\section{Analyses}

This section compares two cases. The main reason for choosing Iran and the UK for this study was their differences in various aspects that helped to compare the roles and functions of social and mobile media during their protests more accurately. On the other hand, the theoretical framework showed the surveillance activities of governments better.

Iran's Green movement was against the fraud in the 2009 presidential election. Mousavi and Karoubi were announced as symbolic leaders of the Green Movement. The protests started in Tehran and expanded to some other major cities. The primary demand of the people was to count the votes again. The protesters changed from angry voters to a nation-wide force demanding freedom and democratic rights for everyone. Initially, they participated in the demonstration in a peaceful manner, but when faced with the violence shown by the police, some of them started to chant more radical slogans. While there were some cases of arson and damage that were rather suspicious and questionable, the Green Movement was largely a peaceful and non-violent movement.

Contrary to the national orientation of Iran's Green Movement, the UK riots were triggered by a completely local event in a marginal region in North London. The protest was described as a criminal case after the death of Mark Duggan. Objections began peacefully but were then stimulated by the police attack. Looting, arson, violent clashes with the police and chaos were the main criteria of the riots in the first hours. In the following days, other parts of London and some major cities witnessed similar incidents. These riots involved the worst violence, damage and destructions in the UK's recent history. While some politicians, journalists, criminologists and academics highlight looting and believe that greed and material aspects were the main motivations behind the UK riots, others emphasize the social injustices and political aspects of riots, and note that riots and looting were messages of dissatisfaction to the authorities; messages of marginalized people to a consumer society, capitalist-based economy and a neoliberal government.

On the other hand, while Iran's Green Movement was a meaningful protest with clear purposes from the start, the UK protests were riots. According to Taylor (2012, abstract) "the 2011 UK riots were unusual for their apparent pointlessness. The significance of the riots was in fact their lack of obvious significance". Furthermore, whilst Iran's Green Movement had leaders in the real world that would announce the movement's aims and strategies (Mousavi 2010; Mousavi and Karroubi 2010), the UK riots did not have any leadership and clear purposes.

\subsection{Comparing The Role of Social and Mobile Media in the Protests}

In order to find the government surveillance in social and mobile media in Iran and the UK, it is necessary to know how protesters used social media and mobile phone during the protests. With this background knowledge, finding the governments' methods of surveillance would be more accurate. Iran and the UK have witnessed several protests during the last decades. But many believe Iran's Green Movement (2009) and the UK riots (2011) were completely different and incomparable with the previous ones. Technology was considered to be the main reason behind this difference. Using mobile phones and different social media 
platforms were mentioned as the most important aspects of technology that impacted both sides of the protests.

While social media and mobile phones were important in both contexts, this should not result in neglecting other media and other influential factors such as economical, political, social and human ones. As some techno-optimists believe social media caused these protests and argue that without new media, these protests would not have occurred, the findings of this study showed that social media and mobile phone were not the root causes of the protests in either of the two countries.

It is obvious that Iran's Green Movement was not a "twitter revolution" or a "social media revolution". The main networks in Iran were not the virtual networks on Facebook or Twitter; the real ones were those networks that were active individuals in the streets. Firstly, because the number of Twitter and Facebook users inside Iran was relatively limited in 2009, and most of the tweets about the election came from outside Iran. Furthermore, the findings revealed that Twitter and Facebook were not influential in the organisation and mobilisation of the protests; on the other hand, they were only very important for publicizing the events. Due to the repressive atmosphere, which involved the banning of independent newspapers and the silence (or negative reaction) from IRIB with regards to the Green Movement, and in the absence of foreign journalists, messages and images were broadcast via Twitter and Facebook to mainstream media. However, mobile phones played a more important role during the movement, with ordinary people learning to act as citizen journalists, taking images and videos and sending them immediately to be broadcast outside the country. The unseen and invisible became seen and visible by new media and technology.

Similarly, in the UK, during the last three years, there have been many discussions about the role of social media and mobile phones in the riots. In these arguments, some have emphasised the negative role of 'social media' that has caused the riots; organised, mobilised, communicated and coordinated the rioters; encouraged the disorder; speeded up the exchange of information; and was responsible for the violence. On the other hand, some social media experts explained that the politicians exaggerated the role of social media in the UK riots. They believe that other than direct or indirect causes of the riots, television played a large part in the spreading of the news of the riots and its role was more important than social media in this regard. In comparison, among the different kinds of social media, BBM was considered the most important tool in the UK riots. On the other hand, some social media platforms such as Twitter and Facebook played a different role, and were used by the people against the rioters to encourage the volunteers and also share information between people, and to organise the clean-up of the streets.

Therefore, while mobile phones were more important than other social media in both cases during the protests, they provided a different functionality in the two countries. In Iran they were used for publicizing the events and in the UK they were employed as an organising tool. Also, social media played both positive and negative roles in support of and against the government in the UK. In Iran, on the other hand, the role played by social media was mainly against the government.

Another difference between Iran and the UK was the leadership of these two protests. While in Iran leadership played a key role in the real world and not in the social media arena, the UK riots suffered from a lack of leaders and were coordinated or led (choreographed ${ }^{1}$ ) by various massages from different BBM users.

Finally, according to some experts' views (El-Nawawy and Khamis 2012) and also my direct observation, many activists in social media, who had the mobilizing role in the Iranian movement, were opposition groups outside Iran, while this was not the case in the UK riots, where the rioters were active locally.

\footnotetext{
${ }^{1}$ This term was borrowed from Paolo Gerbaudo (2012).
} 


\subsection{Comparing Government Surveillance on Social Media and Mobile Phones Commu- nications}

Computerized surveillance is more complicated than other kinds of surveillance. In order to understand government surveillance in social media and mobile phone, the Orwellian and Panoptic models were adopted in this study to analyse the governments' attitudes, policies and actions during the protests. These models helped us to understand how governments used technology to monitor people and to collect information on them for the purpose of controlling protesters as much as possible. These models also helped to find how and why some protesters feared and internalized surveillance.

As mentioned before, government surveillance and electronic surveillance are exemplars of Foucault's image of the Panopticon prison and Orwell's Big Brother (1949). While Orwell showed an atmosphere of fear and pervasive mistrust in society, and the ways the population were monitored and controlled by Big Brother, Foucault compared society with prison, and explained that surveillance is a disciplinary power based on knowledge, gathering, recording, and processing the information of people. In Foucault's model of panopticon (1977; 1980) people are aware that they are being watched at any time. The prison-like society, where invisible observers track our digital footprints, does indeed seem panoptic (Lyon 1994, 71). In this situation, the people internalize surveillance themselves.

While surveillance is the common criterion between governments, the tools for surveillance, the reasons behind it, and their aims may be different. The Iranian government attempted to monitor and limit the protesters' activities on social media and mobile phone networks in the name of national unity, national interest and national security. The main aims for these surveillance policies were security concerns, protecting the national and cultural identity and defence against the import of Western values. The hostile policies of the west towards Iran since the 1979 revolution on the one side, and America's and other Western countries' reactions during the Green movement in Iran in 2009 on the other side strengthened this belief that the aim of the protests was the overthrow of the Islamic Republic of Iran. On the other hand, public order, safety, and security were the main concerns in the UK and the key reasons for government surveillance in the 2011 riots. The United Kingdom as a country with a democratic government was in a paradoxical situation in 2011, and it seems security justified surveillance activities and imposing limitations.

After 2009, the Iranian authorities took some steps towards limiting social media and information flow. The 'Green Movement' demonstrated the shortages of primary filtering and monitoring tools, and forced the Iranian government to pass legislation and devise more complex methods to control and monitor the users.

The main steps the Iranian government took with regards to social media after the 2009 election include the following:

Surveillance and censorship; control of the content made by different social media platforms; blocking Internet communications (Facebook, Twitter, YouTube, and Wikipedia); monitoring, content filtering and blacklisting websites; decrypting e-mails; hacking the Green Movement' websites by cyber army; threatening active websites and activists in cyberspace with legal action; posting online photos of the active protesters on different websites and asking people to identify them; control of the telecommunications industry; creation of "Supreme Council on Cyberspace" as a legal framework; slowing down the Internet to disconnect relation and communication among activists inside Iran and outsiders; and nationalizing Iranian cyberspace.

While some of these activities such as censorship and the filtering of several websites were accepted by the Iranian government before 2009, surveillance policies were strengthened after the protests and found legal justifications to limit the activities in different social media platforms. In this atmosphere, people had a sense of being surveilled in cyberspace, and this feeling increased mistrust and fear in both real and virtual worlds. Subsequently, they internalised this sense of surveillance inside themselves. The dominant political and security atmosphere during the movement adjusted to the two models of study. 
On the other hand, in the UK riots, after David Cameron's statement (2011b) about the role of social media in the disorders, a joint venture between the police and the intelligence services and industries started "to stop people communicating via these services". Despite some primary discussions about the shutting down and blocking of social media, or banning specific users from some platforms in the UK, the UK government found it might be unhelpful, senseless and impracticable to block social media during disorders. Among their reasons were the positive effects that social media could have during the riots or emergencies.

In the UK it seems that it was decided to use social media as an investigative tool rather than censor or block it altogether, which was the method adopted by the Iranian government. Therefore, the Metropolitan Police and law enforcement initiatives used different social media platforms to find participants and organizers of the violence, and rioters for intelligencegathering purposes, and as picture-by-picture, these rioters were being identified and arrested. The Metropolitan police activities, and Cameron's speech when he said 'every contingency is being looked at, nothing is off the table' (2011b) are the main indications that the UK government acted as big brother and had a panoptic policy during the riots.

The act of publicizing the photos of the protesters on different platforms and asking the public to identify them was one of the similarities between the two cases. So, many people were arrested for the messages, images and videos they had sent online in both countries. Furthermore, asking to remove messages, images and videos that could provoke more riots by Cameron was similar to the way the Iranian authorities functioned. On the other hand, during Iran's Green Movement, blocking cellular networks, shutting down text messaging services for over 40 days, monitoring the contacts and texts, controlling the messages by a new "internet crimes" law, providing surveillance technologies through assistance provided by some Western and Chinese companies, and the filtering of some keywords by Iran's telecom operators were the main steps taken by the government.

Furthermore, in the UK riots, not only the UK law but also the UK's Regulation of Investigatory Powers Act strengthened the police in their demand that phone companies hand over information such as who messaged whom, when and from where, and the Cobra decision 'that whatever resources the police need they will get' (Cameron 2011b), assisted them in confronting the rioters. Therefore, while the main policies of Iran with regards to mobile phone communications during the protests was firstly jamming and then monitoring, the UK's main policy was investigating the users. However, in both countries many people were questioned and arrested due to their activities based on their mobile phone communications. Therefore, in both countries the dominant policies about mobile phones reconciled with the Orwellian and Foucauldian models.

To sum up this section, as noted earlier, surveillance was performed by various governments, such as Iran and the UK, with different styles of governance. They surveilled their citizens in a variety of ways and using different tools. Secondly, in both cases, the governments emphasized the importance of social media in protests/riots, and using the same literature. However, the governments' policies such as tracking and monitoring the opponents showed the "double-edged sword" (Thompson 2005,41) nature of the Internet and social media. In this regard, surveillance in social media and mobile phone were their priorities. Publishing the photos of protesters in different social media platforms and asking the public to identify them was one of the most important functions of social media in both countries.

Apart from the different policies of the two governments with regards to mobile phone communications, their co-operation with the companies was similar, which led to the arresting of many protesters.

Moreover, while the UK government had a close cooperation with companies such as Facebook and Twitter in order to monitor British rioters, the Iranian government was deprived of this opportunity. On the contrary, the US State Department asked Twitter to briefly postpone scheduled maintenance in order to keep open lines of communication for the Iranian protesters (Rosett 2009). Facebook, YouTube and Google also provided some added facilities to help Iranian protesters publish contents. 
Another difference between the two cases was the positive functions of social media in the UK, such as the page set up to clean up the streets and to help the government return order to society.

Furthermore, while Iran's main policy was filtering, blocking and shutting down social media and mobile phone communications, the UK government found this policy impracticable, and so it preferred to use social media and BBM in an investigative way, in order to track and then arrest the dissidents during the riots.

\section{Conclusion}

This study has strived to compare the role of social media in two different events with dissimilar aims and causes, on different levels (between the protesters and governments), in distinct times (2009 and 2011), and in two countries that are ruled by two very different kinds of governments (Iran as a Theocratic Islamic Republic state, and the UK as a Democratic Parliamentary Monarchy [DPM]). Furthermore attempts were made to obtain an in-depth understanding of government surveillance of social media and mobile phone during the protests in Iran and the UK.

This research examined the influence of social media and mobile phone communications among protesters during Iran's Green Movement and the UK riots, and studied these events from both optimistic and pessimistic standpoints. Then it drew on the Orwellian concept of Big Brother and the Foucaultian panoptic concept to show how and why governments used social media and what their main policies were in this regard during the crises, in order to examine whether social media and mobile phone communications played influential roles in Iran and the UK.

Therefore, considering the aims and the research question, in summary the findings of the study are:

Firstly, despite the differences in the two cases, social media and mobile phone communications were both important elements besides other factors for activists, protesters, rioters and ordinary people, who were acting as citizen journalists during the protests, and also for people that were against the demonstrators during the protests.

Secondly, social media acted as a "double-edged sword" in Iran and the UK. Both the protesters, and the governments used and benefited from it. The authorities have used social media to monitor, track, threaten, follow and arrest the opposition groups, protesters and rioters. The positive presentation of social media's role in collective action that they are technologies of freedom is put in question by the reality of government surveillance.

The study also found that authorities, irrespective of being theocratic or democratic, justify surveillance of social media and mobile phone communications in the name of protecting public order, security, or national interests. Furthermore, three different methods (direct observation, interview and desk research) for collecting the information, all together prepared a detailed study of these events. Various sources of evidence were employed in order to triangulate the findings of the study, and to increase the validity of the results.

Finally, according to the findings, the Orwellian and Foucauldian models of Big Brother and Panopticon prepared adequate theoretical frameworks to analyse data in both cases. The study confirmed these models are helpful in interpreting how different governments surveilled in cases of political and non-political crises.

The findings of this study have acknowledged the importance of social media and mobile phone communications during and after the protests for both sides: the protesters and the governments. In studying these protests, the impact of other elements, which were deemed to have played a role in triggering, spreading or limiting the protests, should be taken into consideration as well. The study also confirmed that the Orwellian and Foucaultian models are helpful in interpreting how different governments surveilled in cases of political and nonpolitical crises. 


\section{References}

After the Riots: the Final Report of the Riots Communities and Victims Panel. 2012. London: Riots Communities and Victims Panel. Accessed June 7, 2014.

http://webarchive.nationalarchives.gov.uk/20121003195935/http:/riotspanel.independent.gov.uk/wp -content/uploads/2012/03/Riots-Panel-Final-Report1.pdf.

Akwue, Jonathan. 2011a. The Unlikely Social Network Fuelling the Tottenham Riots. Urbonmashup. Accessed May 28, 2014. http://urbanmashup.wordpress.com/2011/08/07/the-unlikely-socialnetwork-fuelling-the-tottenham-riots/.

Akwue, Jonathan. 2011b. The London Riots and BlackBerry's BBM (part 2). Urbonmashup. Accessed May 28, 2014]. http://urbanmashup.wordpress.com/2011/08/08/the-london-riots-and-blackberrysbbm-part-2/.

Alexander, Alison and Jerico Hanson. 2013. Taking sides: Clashing Views in Mass Media and Society. New York, NY: McGraw-Hill/Dushkin.

Alizade, Ali. 2010. Why are the Iranians Dreaming Again? In The People Reloaded: The Green Movement and the Struggle for Iran's Future, edited by Hashemi, Nader and Danny Postel, 3-6. New York: Melville House.

Amnesty International. 2010a. Iran-Amnesty International Report 2010: Human Rights In Islamic Republic Of Iran. London: Amnesty International. Accessed June 17, 2014. http://www.amnesty.org/en/region/iran/report-2010.

Amnesty International. 2010b. From Protest to Prison: Iran One Year After The Election. London: Amnesty International. Accessed June 17, 2014. http://www.amnestyusa.org/research/reports/fromprotest-to-prison-iran-one-year-after-the-election.

Anden-Papadopoulos, Kari. 2014. Citizen Camera-witnessing: Embodied political dissent in the age of 'mediated mass self-communication'. New Media \& Society 16 (5): 753-769. Accessed August 9, 2014. http://nms.sagepub.com/content/16/5/753.full.pdf+html, http://nms.sagepub.com/content/early/2013/05/30/1461444813489863.full.

Andrerjvic, Mark. 2007. iSpy: surveillance and power in the interactive era. Lawrence, Kan: University Press of Kansas.

Axworthy, Michael. 2014. Revolutionary Iran: A history of the Islamic Republic. London: Penguin Books.

Bakhtavar, Slater. 2009. Iran: The Green Movement. Texas: Parsa Enterprises, LLC.

BBC. 2009. The Warning of The Iranian Revolutionary Guard Corps (IRGC) To the Weblogs and Websites. Accessed July 27, 2014. http://www.bbc.co.uk/persian/iran/2009/06/090617_ka_ir88_sepah internet.shtml.

BBC. 2011. London riots: Looting and violence continues. Accessed June 1, 2014. http://www.bbc.co.uk/news/uk-england-london-14439970.

Bentham, Jeremy. 2008. Panopticon, Or, the Inspection-House. S.I: Dodo press.

Beth Elson, Sara et al., 2012. Using Social Media to Gauge Iranian Public Opinion and Mood After the 2009 Election. Santa Monica: RAND Corporation. Accessed: August 1, 2014. http://www.rand.org/content/dam/rand/pubs/technical_reports/2012/RAND_TR1161.pdf.

Bridges, Lee. 2012. Four days in August: the UK riots. Race \& Class 54 (1): 1-12. Accessed May 28 , 2014 http://rac.sagepub.com/content/54/1/1.full.

Brito, Jerry. 2011. After Riots, London Crowdsources Cleanup, Identifying Looters. Techland. Accessed May 25, 2014. http://techland.time.com/2011/08/09/after-riots-london-crowdsources-cleanupidentifying-looters/.

Boghosian, Heidi. 2013. Spying on democracy: government surveillance, corporate power, and public resistance. San Francisco: City Lights Publishers.

Bozovic, Miran. 1995. Introduction. In: Bentham, Jeremy and Miran Božovič. The Panopticon and other prison writings. New York: Verso.

Cameron, David. 2011a. UK riots: David Cameron's statement in full. The Telegraph. Accessed July 8, 2014. http://www.telegraph.co.uk/news/uknews/crime/8693134/UK-riots-David-Cameronsstatement-in-full.html.

Cameron, David. 2011b. PM statement on disorder in England. Gov.UK. Accessed July 8, 2014. https://www.gov.uk/government/news/pm-statement-on-disorder-in-england.

Carrieri, Matthew et al., 2013. After the Green Movement Internet controls in Iran, 2009-2012. OpenNet Initiative. Accessed December 17, 2013. https://opennet.net/sites/opennet.net/files/iranreport.pdf. 
Casilli, Antonio and Paolo Tubaro. 2012. Social Media Censorship in Times of Political Unrest - A Social Simulation Experiment with the UK Riots. Bulletin of Sociological Methodology/Bulletin de Methodologie Sociologique 115 (5): 5-20. Accessed May 29, 2014. http://bms.sagepub.com/content/115/1/5.

Castells, Manuel. 2001. The Internet Galaxy. Oxford: Oxford university press.

Castells, Manuel. 2012. Networks of Outrage and Hope: Social Movements in the Internet Age. Cambridge: Polity.

Cellan-Jones, Rory. 2009. Hi-tech helps Iranian monitoring. BBC. Accessed July 26, 2014. http://news.bbc.co.uk/1/hi/technology/8112550.stm.

Chadwick, Andrew. 2006. Internet politics: states, citizens, and communication technologies. New York: Oxford University Press.

Cross, Kevin. 2010. Why Iran's Green Movement Faltered: The Limits of Information Technology in a Rentier State. SAIS Review of International Affairs. 30(2), 169-187. Accessed July 26, 2014. http://muse.jhu.edu/login?auth=0\&type=summary\&url=/journals/sais review/v030/30.2.cross.pdf.

Cyber Police. 2009. Cyber Crimes’ List. Iran: Cyber Police. Accessed July 17, 2014. http://www.cyberpolice.ir/page/2551.

Dabashi, Hamid. 2010. Iran, the green movement and the USA: The fox and the paradox. London: Zed Books. Accessed 15 May 15, 2014. http://public.eblib.com/EBLPublic/PublicView.do?ptilD=619254.

Dzieza, Josh. 2011. Caught Red-Thumbed. The Daily Beast. Accessed July 8, 2014. http://www.thedailybeast.com/articles/2011/08/12/london-riots-police-use-social-media-to-trackrioters.html.

Department for Communities and Local Government. 2013. Government Response to the Riots, Communities and Victims Panel's final report. Department for Communities Local Government. Accessed June 7, 2014.

https://www.gov.uk/government/uploads/system/uploads/attachment_data/file/211617/Govt_Respo nse to the Riots - Final Report.pdf.

El-Nawawy, Mohammad. 2012. Hear it From the Experts, Digital Media in Iran. SMU (Singapore Management University). Accessed June 10, 2014. https://wiki.smu.edu.sg/digitalmediaasia/Digital_Media_in_Iran\#cite_note-2.

El-Nawawy, Mohammad and Sahar Khamis .2012. Political Activism 2.0: Comparing the Role of Social Media in Egypt's "Facebook Revolution" and Iran's "Twitter Uprising". CyberOrient, Online Journal of the Virtual Middle East 6 (1). Accessed August 5, 2014. http://www.cyberorient.net/article.do?articleld=7439.

Ems, Lindsay. 2014. Twitter's place in the tussle: how old power struggles play out on a new stage. Media Culture \& Society. 36 (5), 720-731. Accessed June 7, 2014. http://mcs.sagepub.com/content/early/2014/06/04/0163443714529070.full.

Evans, Mark. 2009. A Look at Twitter in Iran. Sysomos. Accessed August 2, 2014. http://blog.sysomos.com/2009/06/21/a-look-at-Twitter-in-iran/.

Fars news Agency. 2009. News. Accessed June 17, 2014. http://farsnews.com/.

Fassihi, Farnaz. 2009. Iranian Crackdown Goes Global. The Wall Street Journal. December 3. Accessed June 17, 2014. http://online.wsj.com/news/articles/SB125978649644673331.

Foucault, Michel.1977. Discipline and Punish: The Birth of the Prison, Harmondsworth: Penguin.

Foucault, Michel.1980. The Eye of Power. Accessed July 4, 2014. http://www.google.co.uk/url?sa=t\&rct=j\&q=\&esrc=s\&source=web\&cd=3\&ved=0CDoQFjAC\&url=http $\% 3 \mathrm{~A} \% 2 \mathrm{~F} \% 2 \mathrm{Fnbrokaw}$.files.wordpress.com $\% 2 \mathrm{~F} 2010 \% 2 \mathrm{~F} 12 \% 2 \mathrm{Fthe}-\mathrm{eye}$-ofpower.doc\&ei=J8N8UvLaK8G2hQfDyoHgCQ\&usg=AFQjCNFJqw7alNOYIJoHenZOzNeybo5I7w\&bvm= bv.56146854,d.ZG4.

Freedom House. 2009. Special Report: Iran. Accessed June 14, 2014. http://www.sssup.it/UploadDocs/4661_8_A_Special_Report_Iran_Feedom_House_01.pdf.

Freedom House. 2011. Freedom on the Net: Iran. Accessed June 29, 2014. https://freedomhouse.org/report/freedom-net/2011/iran - .VWr722RVikp.

Fuchs, Christian. 2011. Social Media and the UK Riots: Twitter Mobs, Facebook Mobs, Blackberry Mobs and the Structural Violence of Neoliberalism. Christian Fuchs/Information-SocietyTechnology \& Media. Accessed June 17, 2014. http://fuchs.uti.at/667/.

Fuchs, Christian. 2012. Social media, riots, and revolutions. Capital \& Class 36 (3): 383-391. 
Fuchs, Christian, Kees Boersma, Anders Albrechtslund and Marisol Sandoval (eds). 2012. Internet and Surveillance: the Challenges of Web 2.0 and Social Media. New York: Routledge.

Fuchs, Christian. 2013. Societal and ideological impacts of Deep Packet Inspection (DPI) Internet surveillance. Information, Communication and Society 16 (8): 1328-1359. Accessed April 26, 2015. http://www.tandfonline.com/doi/full/10.1080/1369118X.2013.770544\#.

Fuchs, Christian. 2014. Social Media: A Critical Introduction. London: Sage.

Gabbatt, Adam and Ben Quinn. 2011. London Disturbances. The Guardian. Accessed May 28, 2014. http://www.theguardian.com/uk/blog/2011/aug/07/tottenham-riots-police-duggan-live.

Gerbaudo, Paolo. 2012. Tweets And The Streets: Social Media And Contemporary Activism. London: PlutoPress.

Gill, Stephen. 2003. Globalization, Market Civilization and Disciplinary Neoliberalism. In Globalization: critical concepts in sociology, edited by Roland Robertson and Kathleen White, 256-281. London: Routledge.

Gladwell, Malcolm. 2010. Small Change: Why the Revolution will not be tweeted? The New Yorker. October: 42-49. Accessed July 18, 2014. http://www.newyorker.com/magazine/2010/10/04/smallchange-malcolm-gladwell

Global Post. 2011. Social Media Blamed for London Riots. Accessed August 4, 2014. http://www.globalpost.com/dispatch/news/regions/europe/110808/social-media-blamed-londonriots.

GM Police. 2011. London: Greater Manchester Police Profile. Accessed July 21, 2014. https://twitter.com/gmpolice/status/101067338232770561.

Goodman, David. 2011. Private Messaging Network Is Said to Link London Rioters. The Lede. Accessed May 30, 2014. http://thelede.blogs.nytimes.com/2011/08/08/private-social-network-said-tolink-london-rioters/? php=true\& type=blogs \& $r=0$.

Halliday, Josh. 2011a. London riots: BlackBerry to Help Police Probe Messenger Looting 'Role'. The Guardian. Accessed May 30, 2014. http://www.theguardian.com/technology/2011/aug/09/londonriots-blackberrys-police.

Halliday, Josh. 2011b. London Riots: Police to Track Rioters who used BlackBerrys. The Guardian. Accessed May 30, 2014. http://www.theguardian.com/technology/2011/aug/09/london-riotsblackberrys-police.

Halliday, Josh. 2011c. David Cameron Considers Banning Suspected Rioters from Social Media. The Guardian. Accessed May 30, 2014. http://www.theguardian.com/media/2011/aug/11/davidcameron-rioters-social-media.

Holmwood, Leigh and Saeed Kamali Dehghan. 2009. Iran Widens Jamming of BBC as Revolutionary Guard Cautions Bloggers. The Guardian. Accessed July 18, 2014. http://www.theguardian.com/media/2009/jun/17/iran-bbc-jamming-bloggers-revolutionary-guard.

Home Affairs Committee. 2011. Home Affairs Committee Concludes Police Failed to Appreciate Magnitude of Riot Task. Parliament Home Page. Accessed May 16, 2014. http://www.parliament.uk/business/committees/committees-a-z/commons-select/home-affairs-committee/news/plsdreport-publication/.

IFSEC Global. 2011. Riots in the UK: Theresa May to chair meeting on social media with law enforcement agencies. IFSEC Global. Accessed June 6, 2014. http://www.ifsecglobal.com/riots-inthe-uk-theresa-may-to-chair-meeting-on-social-media-with-law-enforcement-agencies/.

Internet World Stats News. 2009. The Internet Hits 1.5 Billion. Accessed July 3, 2014. http://www.internetworldstats.com/pr/edi038.htm.

Internet World Stats. 2012. Iran. Accessed June 5, 2014. http://www.internetworldstats.com/me/ir.htm. Internet World Stats. 2010. United Kingdom. Accessed June 5, 2014. http://www.internetworldstats.com/eu/uk.htm.

Internet World Stats. 2014. European Union. Internet World Stats. Accessed June 5, 2014. http://www.internetworldstats.com/europa.htm.

Internet World Stats. 2014. Middle East. Accessed June 5, 2014. http://www.internetworldstats.com/middle.htm.

Iran Media Program. 2013. Text Messaging as Iran's New Filtering Frontier. Accessed July 25, 2014. http://www.iranmediaresearch.org/en/blog/227/13/04/25/1360.

IRNA News Agency. 2009. News. Accessed June 18, 2014. http://www.irna.ir/?LANG=EN.

ISNA News Agency. 2009. News. Accessed June 18, 2014. http://www.isna.ir/.

Jaras. 2009. Internet: Iran's New Imaginary Enemy. Accessed June 28, 2014. http://www.rahesabz.net/print/12143. 
Jones, Sam, Matt Wells and Paul Owen. 2011a. London and UK Riots Day Three AftermathTuesday 9 August 2011. The Guardian. Accessed June 1, 2014. http://www.theguardian.com/uk/blog/2011/aug/09/london-riots-violence-lootinglive?guni=Article:in\%20body\%20link.

Jones, Sam, Matt Wells, Paul Owen, and Ben Quinn. 2011b. London Riots and UK Unrest-Tuesday 9 August 2011. The Guardian. Accessed June 1, 2014. http://www.theguardian.com/uk/blog/2011/aug/09/london-riots-day-four-liveblog?guni=Article:in\%20body\%20link.

Lewis, Paul, et al., 2011. Reading the Riots: investigating England's summer of disorder. London: Guardian/LSE. Accessed May 20, 2014. http://eprints.Ise.ac.uk/46297/1/Reading\%20the\%20riots(published).pdf.

Lyon, David.1994. The electronic eye: The rise of surveillance society. Minneapolis: University of Minnesota Press.

Lyon, David. 2001. Surveillance Society: Monitoring everyday life. Buckingham and Philadelphia: Open University Press.

Lyon, David. 2006. Theorizing surveillance: the panopticon and beyond. Cullompton: Devon, Willan Publishing.

Lyon, David. 2007. Surveillance Studies: an Overview. Cambridge: Polity Press.

Marx, Gary. T. 2002. What's New about the "New Surveillance"? Classify for Change and Continuity. Surveillance \& Society 1 (1): 9-29. Accessed 12 May 2014. http://www.surveillance-andsociety.org/articles $1 /$ whatsnew.pdf

May, Theresa. 2011a. Oral statement to Parliament Riots: Theresa May's speech on 11 August 2011. Gov.UK. Accessed June 6, 2014. https://www.gov.uk/government/speeches/riots-theresa-maysspeech-on-11-august-2011.

May, Theresa. 2011b. Social media industry representatives visit Home Office. Gov.UK. Accessed June 18, 2014. https://www.gov.uk/government/news/social-media-industry-representatives-visithome-office.

McMillan, Graeme. 2011. U.K. Government Considers Blocking Twitter, BlackBerry in Wake of Riots. Time. Accessed June 1, 2014. http://techland.time.com/2011/08/11/u-k-government-considers-blockingtwitter-blackberry-in-wake-of-riots/.

Meikle, Graham and Sherman Young. 2012. Media Convergence: Networked Digital Media in Everyday Life. London: Palgrave Macmillan.

Metropolitan Police. 2011. Contact us. Accessed June 1, 2014. http://content.met.police.uk/Site/operationwithemcontactus.

Metropolitan Police. 2012. Metropolitan Police Service, Strategic Review into the Disorders of August 2011_Final Report. London: Metropolitan Police. Accessed June 5, 2014.

http://content.met.police.uk/cs/Satellite?blobcol=urldata\&blobheadername1=ContentType\&blobheadername2=Content-

Disposition\&blobheadervalue $1=$ application/pdf\&blobheadervalue2=inline; +filename $=\% 22145 / 595 /$ co553114DaysInAugust.pdf\%22\&blobkey=id\&blobtable=MungoBlobs\&blobwhere $=1283551523589 \& s s b i$ nary=true.

Milburn, Keir. 2012. The August riots, shock and the prohibition of thought, Capital \& Class 36 (3): 401-409. Accessed April 25, 2015. http://cnc.sagepub.com/content/36/3/401.full.pdf+html.

Ministry of Justice. 2012. Statistical Bulletin on the Public Disorders of 6th to 9th August 2011 September 2012 Update. London: Ministry of Justice. Accessed May 15, 2014. https://www.gov.uk/government/uploads/system/uploads/attachment_data/file/219665/augustpublic-disorder-stats-bulletin-130912.pdf.

Morell, Gareth et al. 2011. The August riots in England: Understanding the involvement of young people. London: National Centre for Social Research. Accessed June 21, 2014. https://www.gov.uk/government/uploads/system/uploads/attachment_data/file/60531/The_20Augus t_20Riots_20in_20England_20_pdf_201mb_pdf.

Morozov, Evgeny. 2010. Why the Internet is Failing Iran's Activists. Prospect. Accessed June 15, 2014. http://www.prospectmagazine.co.uk/magazine/why-the-internet-is-failing-iransactivists/\#.u56x4i ixha.

Morozov, Evgeny. 2011. The Net Delusion: the Dark Side of Internet. New York: NY, Public Affairs.

Mousavi, Mir Hussein. 2010. Mousavi's Important Speech about the Aims and Strategy of Iranian Green Movement. Jaras. Accessed June 17, 2014. http://www.rahesabz.net/print/14156. 
Mousavi, Mir Hussein and Mehdi Karroubi. 2010. Iran's Green Movement Charter. Kaleme. Accessed June 17, 2014. http://www.kaleme.com/1389/12/03/klm-48610/.

Ofcom. 2011. A nation addicted to smartphones. Accessed 6 June 6, 2014. http://media.ofcom.org.uk/2011/08/04/a-nation-addicted-to-smartphones/.

Open Net Initiative. 2009. Iran. Accessed June 26, 2014. https://opennet.net/research/profiles/iran.

Orwell, George. 1949. Nineteen eighty-four. A novel. New York: Harcourt, Brace \& Co.

Petersen, Julie. K. 2013. Introduction to surveillance studies. Boca Raton: CRC Press, Taylor \& Francis Group.

Pfanner, Eric. 2011. Cameron Exploring Crackdown on Social Media After Riots. The New York Times. Accessed June 6, 2014. http://www.nytimes.com/2011/08/12/world/europe/12ihtsocial12.html? $r=1 \&$.

Platts-Fowler, Deborah, 2013. Beyond the loot': Social disorder and urban unrest. The British Society of Criminology 13. Accessed April 26, 2015. http://britsoccrim.org/new/volume13/pbcc 2013_Platts-Fowler.pdf.

Procter, Rob, Farida Vis and Alex Voss. 2011. How Riot Rumours Spread on Twitter. The Guardian. Accessed July 21, 2014. http://www.theguardian.com/uk/interactive/2011/dec/07/london-riotstwitter.

Reilly, Paul. 2013. Every Little Helps? YouTube, Surveillance and the 'Anti-Tesco' Riot in Stokes Croft. New Media \& Society: 1-17. Accessed May 29, 2014. http://nms.sagepub.com/content/early/2013/11/19/1461444813512195.full.pdf+html.

Reporters Without Borders. 2010. Web 2.0 versus Control 2.0. Accesses May 27, 2014. http://en.rsf.org/web-2-0-versus-control-2-0-18-03-2010,36697.

Resnick, D. 1998. Politics on the Internet: The Normalization of Cyberspace. In The Politics of Cyberspace: A New Political Science Reader, edited by Chris Toulouse and Timothy W. Luke, 48-68. New York: Routledge.

Rogers, Simon. 2011. England riots: which shops were looted? The Guardian, 6 December. Accessed June 4, 2014. http://www.theguardian.com/uk/datablog/2011/dec/06/england-riots-shops-raided.

Rosset, Claudia. 2009. The Green Rebellion Forbes, Accessed June 10, 2014. http://nww.forbes.com/2009/06/17/iran-election-ahmadinejad-mousavi-opinions-columnists-green-rebellion.html

Schwartz, Mathew J. 2011. U.K. Police Seek BlackBerry Messages Following Riots. Dark Reading. Available from: Accessed June 1, 2014. http://www. darkreading.com/risk-management/uk-police-seekblackberry-messages-following-riots/d/d-id/1099447.

Shirky, Clay. 2011. The Political Power of Social Media: Technology, The Public Sphere, and Political Change. Foreign Affairs. Accessed June15, 2014. https://www.foreignaffairs.com/articles/2010-1220/political-power-social-media .

Singh, Darra et al., 2012. After the riots: The final report of the Riots Communities and Victims Panel: riots communities and victims panel. The Riots Communities and Victims Panel. Accessed June 6, 2014.

http://webarchive.nationalarchives.gov.uk/20121003195935/http:/riotspanel.independent.gov.uk/wp -content/uploads/2012/03/Riots-Panel-Final-Report1.pdf.

Social News Corps. No Dates. Social Media Iran. Iranian Social Media News Network-San Francisco, CA. Accessed August 1, 2014. http://socialmediairan.com/.

Stelter, Brian and Brad Stone. 2009. Stark Images, Uploaded to the World. The New York Times. Accessed August 1, 2014. http://www.nytimes.com/2009/06/18/world/middleeast/18press.html.

Sullivan, Andrew. 2009. The Revolution Will Be Twittered. The Atlantic. Accessed June16, 2014. http://www.theatlantic.com/daily-dish/archive/2009/06/the-revolution-will-be-twittered/200478/.

Taylor, Paul Anthony. 2012. The Just Do It riots: A critical interpretation of the media's violence. Capital \& Class 36 (3): 393-399. Accessed April 26, 2015. http://cnc.sagepub.com/content/36/3/393.abstract.

The Economists. 2011. The BlackBerry Riots. Accessed June 3, 2014. http://www.economist.com/node/21525976?fsrc=scn/fb/wl/ar/blackberryots.

The Guardian. 2011. Reading the Riots. The Guardian. Accessed May 25, 2014. http://www.theguardian.com/uk/series/reading-the-riots.

Thompson, John B. 2005. The New Visibility, Theory, Culture \& Society, 22 (6): 31-51. Accessed July 28, 2014. http://tcs.sagepub.com/content/22/6/31.full.pdf+html.

Tribunal Decision. no date. Immigration and Asylum Chamber: Decisions on Appeals to the Upper Tribunal. Accessed July 22, 2014. http://www.tribunalsdecisions.service.gov.uk. 
Trottier, Daniel. 2011. A Research Agenda for Social Media Surveillance. Fast Capitalism 8 (1). Accessed 24 July 2014. http://www.uta.edu/huma/agger/fastcapitalism/8 1/trottier8 1.html.

Tusa, Felix. 2013. How Social Media Can Shape a Protest Movement: The Cases of Egypt in 2011 and Iran in 2009. Arab Media and Society 17. Accessed July 15, 2014 http://www.arabmediasociety.com/index.php?article $=816 \& p=0$.

Valizadeh, Reza. 2011. Invitation to the public shooting with the camera. RFI. Accessed June 19, 2014. http://www.persian.rfi.fr/\%D8\%AF\%D8\%B9\%D9\%88\%D8\%AA-\%D8\%A8\%D9\%87\%D8\%B4\%D9\%84\%DB\%8C\%DA\%A9-\%D8\%B9\%D9\%85\%D9\%88\%D9\%85\%DB\%8C\%D8\%A8\%D8\%A7-\%D8\%AF\%D9\%88\%D8\%B1\%D8\%A8\%DB\%8C\%D9\%86\%D8\%B9\%DA\%A9\%D8\%A7\%D8\%B3\%DB\%8C$20110307 / \%$ D8\%A7\%DB\%8C\%D8\%B1\%D8\%A7\%D9\%86.

Wagner, Ben. 2012. Exporting Censorship And Surveillance Technology, Netherlands: Humanist Institute for Co-operation with Developing Countries (Hivos). Accessed July 7, 2014. https://hivos.org/sites/default/files/exporting_censorship_and_surveillance_technology_by_ben_wa gner.pdf.

Web Ecology Project (WEP). 2009. The Iranian Election On Twitter: The First Eighteen days. Web Ecology project. Accessed June 29, 2014. http://www.webecologyproject.org/wpcontent/uploads/2009/08/WEP-twitterFINAL.pdf.

Wells, Matt and Same Jones. 2012. London Riots Aftermath. The Guardian. http://www.theguardian.com/uk/2011/aug/08/london-riots-tottenham-duggan-blog.

WikiLeaks. 2011. The Spyfiles. Accessed 10-15 March, 2014. https://www.wikileaks.org/the-spyfiles.html. World Bank. No date. Mobile cellular subscriptions (per 100 people). The World Bank. Accessed June 27, 2014. http://data.worldbank.org/indicator/IT.CEL.SETS.P2.

\section{About the Author}

\section{Jamileh Kadivar}

Jamileh Kadivar is a freelance journalist and a political analyst. She holds an MA in International Relations from the University of Tehran, an MA in Social Media from the University of Westminster, and a $\mathrm{PhD}$ in Political Science from the University of Tehran. She used to be a lecturer in the Women and Family Studies department in Alzahra University in Tehran. 